\title{
Kapadokya'da Turistik Ürün Olarak Kamping mi Glamping mi?
}

\author{
Şule Ardıç Yetiş ${ }^{1 *}$ \\ ${ }^{1}$ Nevşehir Hacı Bektaş Veli Üniversitesi, Turizm Fakültesi, ardicsule@nevsehir.edu.tr, ORCID: 0000-0002-8792-9079
}

Öz

Bu çalışmada, Kapadokya Bölgesi'nin kamp turizmi açısından mevcut durumunu incelemek ve bu kapsamda yeni bir turizm türü olarak glamping kapsamında bölgenin neler yapabileceğine ilişkin öneriler sunabilmek amaçlanmaktadır. Çalışmada birincil ve ikincil veriler kullanılmıştır. Birincil veriler yarı yapılandırılmış mülakatlardan, ikincil veriler ise daha önce yapılmış çalışmalardan elde edilmiştir. Bu verilerle GZTF (SWOT) analizi ile Kapadokya Bölgesi'nin kamp ve karavan turizmi açısından mevcut durumu değerlendirilmiştir. Çalışmada, kamp işletmelerinin glamping işletmelerine dönüşebilmesinde temel ihtiyaçların ötesine geçmelerinin gereği ortaya konmuştur. Ayrıca destinasyonun kamp turizmi açısından önemli bir bilinirliğinin olduğu ve mevcut kamping işletmelerinin hizmetlerinde kalite düzeylerini artırmaları ile bölgenin kamping destinasyonundan glamping için bir alternatif destinasyon olabileceğine ulaşılmıştır.

Anahtar Kelimeler: Turistik Ürün, Kamp Turizmi, Glamping, Kapadokya Bölgesi

\section{Camping or Glamping as a Tourist Product in Cappadocia?}

Abstract

\begin{abstract}
In this study, it is aimed to examine the current situation of the Cappadocia Region in terms of camping tourism and to offer suggestions about what the region can do within the scope of glamping tourism as a new type of tourism. Primary and secondary data were used in the study. Primary data were obtained from semi-structured interviews and secondary data were obtained from previous studies. With these data, the current situation of the Cappadocia Region in terms of camping and caravan tourism was evaluated with SWOT analysis. In the study, the necessity of going beyond basic needs for camping businesses to turn into glamping businesses is revealed. In addition, it has been reached that the destination has an important recognition in terms of camping tourism and that the current camping businesses increase their quality levels in their services, and the region can be an alternative destination for glamping from the camping destination.
\end{abstract}

Keywords: Touristic Product, Camping Tourism, Glamping, Cappadocia Region
Araştırma Makalesi

Cilt 5, Sayı 1, 2021

ss. $131-148$

Gönderim : 08.02.2021

1. Düzeltme: 09.03.2021

Kabul Tarihi: 12.03 .2021

\section{Research Article}

Vol 5, No 1, 2021

pp. $131-148$

Received : 08.02.2021

Revision1: 09.03.2021

Accepted: 12.03 .2021

Önerilen Atıf/Suggested Citation

Ardıç Yetiş, Ş. (2021). Kapadokya'da Turistik Ürün Olarak Kamping mi Glamping mi?. Güncel Turizm Araştırmaları Dergisi, 5(1), 131-148.

*Sorumlu yazar e-posta: ardicsule@nevsehir.edu.tr 


\section{GíRiş}

Günlük yaşamdaki yoğunluk, kişileri doğrudan etkilemekte, yaşam tarzlarını olumlu veya olumsuz olarak etkilemektedir. Şehir yaşamının getirdiği yoğun çalışma, gürültü, trafik ve kalabalık, bunların getirisi olarak çevre kirliliği gibi nedenler kişileri boş zamanlarında kırsal alanlarda vakit geçirmeye iten sebepler arasında yer almaktadır. Bu doğrultuda insanlar; doğa ile iç içe olmak, rahatlamak, huzur bulmak ve yenilenmek amacıyla gerçekleştirilebilen doğa temelli dinlence ve eğlenceye ya da rekreatif etkinliklere yönelmektedir (Öztürk ve Başarangil, 2019: 1189). Bahsedilen nedenler, kişilerin turistik ihtiyaçlarında da doğa temelli aktiviteleri tercih etmelerine neden olmakta ve kamp yapmaya uygun destinasyonlar cazibe merkezleri olmaktadır.

Modern turistler, yaşadıkları deneyimlerden keyif alan, bilgili ve yerel unsurları görmeye hevesli kişilerdir. Bu durum turistlerin ihtiyaçlarını ve isteklerini daha karmaşık hale getirmektedir. Değişen turizm eğilimleri, yeni ve farklı konaklama türlerine olan talebin artmasına neden olmaktadır. Ayrıca doğaya dönüş eğiliminin artması, turistlerin artan ekolojik farkındalığı ve sürdürülebilirlik bilinci, turizm sektöründe doğa temelli hizmet veren kamplara ve benzer konaklama işletmelerine olan talebin artmasına neden olmaktadır. Öte yandan lüks tüketimden vazgeçmek istemeyen orta ve yüksek gelir sahibi turistler de doğa temelli aktivitelere katılmak istemektedir. Bu kapsamda açık havada, doğa ile iç içe yapılan kamp aktiviteleri en çok tercih edilen doğa temelli rekreatif bir etkinlik olarak kabul edilmektedir (Lee, Lee ve Moon, 2019).

$\mathrm{Bu}$ doğrultuda lüks ile doğayı birleştirebilecek bir turistik ürün ihtiyacı ortaya çıkmaktadır. Lüks tüketimi çağrıştıran büyüleyici ve göz alıcı kelimelerini ifade eden "glamorous" ile açık havada kamp yapma anlamına gelen "camping" kelimelerinin birleşmesi ile "glamping" kavramı gündeme gelmektedir. Bununla birlikte kamp alanlarındaki yenilikçi bir konaklama şekli olan glamping, kalitenin ve rekabetçiliğin artırılmasına yönelik yeni bir stratejik değişim yaratmaktadır. Kapadokya Bölgesi tarihi ve doğal güzellikleri ile eşsiz turistik destinasyonlardan biridir. Aynı zamanda Kapadokya Bölgesi'nde ilk turistik aktiviteler kamp ve karavan faaliyetleri olarak başlamıştır. Günümüzde Kapadokya Bölgesi yerli ve yabancı birçok turistin ziyaret ettiği bir turistik destinasyondur. Gelen turistlerin farklı konaklama ve eğlence beklentileri vardır. Bu beklentileri karşılamak için bölgede kaya oyma otellerin yanı sıra farklı konseptte kamp işletmeleri de yer almaktadır.

$\mathrm{Bu}$ çalışma, Kapadokya Bölgesi'nin kamp ve karavan turizmi açısından mevcut durumunu incelemeyi ve yeni bir turizm türü olarak glamping kapsamında bölgenin neler yapabileceğine ilişkin öneriler sunabilmeyi amaçlamaktadır. Dolayısıyla Kapadokya Bölgesi hem doğa temelli aktivitelere katılmak isteyen turistlere yönelik turistik ürünlerin özellikleri açısından değerlendirilmesine hem de bölgede bu konu ile ilgili çalışmaların artırılmasına dikkat çekileceği düşünülmektedir. Bu kapsamda çalışmada öncelikle kamping ve glamping kavramlarından ve bu aktivitelerin turizm çeşidi olarak kullanılmasında oluşan farklılıklara değinilecek, ardından Kapadokya Bölgesi kamping ve glamping turizmi kapsamında değerlendirilecektir. 


\section{LİTERATÜR TARAMASI}

\section{Kamping ve Glamping Kavramlarına Genel Bir Bakış}

Kampçılık, ikamet edilen yerin dışında genellikle parklar ve korunan alanlarda gerçekleştirilen ve doğal bir ortamda bir veya daha fazla gece geçirilen doğa temelli bir turizm biçimi olarak kabul edilmektedir (Hewer, Scott ve Gough, 2017: 1806). Anderson (1979), bir eğitim ve eğlence etkinliği biçimi olarak kampçllğın (camping) köklerinin Antik Yunan'a dayandığını ve Spartalılar'ın kampı bir fiziksel eğitim biçimi olarak kullandıklarını ifade etmiştir. Amerika Birleşik Devletleri'nde ve Avrupa'da kampçılık, 1800'lerde yapılan ilk sömürüler sonrası popüler hale gelmiş ve konu ile ilgili ilk kitap (Campers Handbook) 1903'te yayınlanmıştır. Günümüzdeki kampçllık, 1900'lerde bisiklet ve otomobilin tanıtımıla bilinirliğini kazanmış ve özellikle Amerika Birleşik Devletleri'nde, parkurların, kamp alanlarının ve milli parkların gelişimi kampçılı̆̆ın büyümesinde etkili olmuştur (Gürsoy ve Chen, 2012).

Kamp alanları, karayolları ve yakın çevrelerinde, il ve ilçe girişlerinde, deniz, göl, dağ gibi destinasyona özgü cazibesi olan yerlerde kurulan ve genellikle kampçların kendi imkânları ile geceleme, yeme-içme, dinlenme ve eğlence ihtiyaçlarını karşıladıkları karavan, çadır, bungalov gibi en az otuz ünitelik mekânlardır (Tursab, 2019). Bununla birlikte Avrupa İstatistik Ofisi'nin (EUROSTAT) 2018 raporuna göre, Avrupa'da turistik yatak kapasitesinin yaklaşık \%31'inin kamp alanlarında bulunduğu ifade edilmektedir (Salo, Teixidor, Fluvia, ve Garriaga, 2020).

Kampçllık, olumlu ve olumsuz birçok etkiye sahiptir. Kampçılık ile turistler ve doğal çevre arasındaki zengin bir ilişkinin kurulması veya bu ilişkinin yenilenmesi sağlanmaktadır (Lee vd., 2019). Kampçılı̆̆ın fiziksel ve zihinsel iyileşme (Louv, 2005; Shultis, 2003), günlük yaşamın stresini azaltma (Ulrich vd., 1991) ve artan sosyal uyum (Borrie ve Roggenbuck, 2001) gibi olumlu etkileri bulunmaktadır. Turistlerin kamp yaparken yaşadıkları deneyimler ve bunlarla ilgili anlamlar hakkında daha fazla bilgi sahibi olmak, farklı etkiler elde edilmesine yardımcı olabilmekte ve potansiyel olarak insan-çevre ilişkisini geliştirebilmektedir (Hassel, Moore ve Macbeth, 2015: 270). Bu olumlu etkilerin yanı sıra kamp alanında yapılan faaliyetlerin hava kalitesinin bozulması, toprak oluşumunun ve alanda yer alan floranın zarar görmesi, su kirliliği, biyolojik çeşitliliğin zarar görmesi, karbon emisyonunun oluşması gibi olumsuz etkileri de söz konusudur (Stettler, 2011).

Öte yandan kampçılık; stresten kaçış, sosyalleşme, özgürlük ve keşfetme motivasyonları ile oluşan alternatif bir konaklama ya da yaşam biçimi olarak macera sever turistlere yönelik bir aktivite olarak bilinmektedir (Brooker ve Joppe, 2013). Turistler tarafından en fazla tercih edilen doğa temelli turizm biçimi olan kampçılık (O'Neill, Riscinto-Kozub ve Van Hyfte, 2010), diğer konaklama işletmelerinden farklı olarak ucuz konaklama ve yeme-içme, eğlence faaliyetlerinin katılımcıların kendi imkânları ile yapabilmesini sağlamaktadır (Wellner, 2015: 61). Aynı zamanda kampçlık, alt gelir seviyesine sahip aileler ve gençler tarafından tercih edilmektedir (Mikulic, Prebezac, Seric ve Kresic, 2017: 226). Çocuklu aileler veya ileri yaşlı çocuksuz aileler için kamp yapmak bir kaçıs, tatil ve uygun bir konaklama şeklidir (Hardy, 
Hanson ve Gretzel, 2012). Kampçılar doğa ile iç içe konaklamanın yanı sıra balık tutma, avlanma, yüzme, bitkileri, kuşları ve yaban hayatı inceleme ve izleme, doğayı fotoğraflama gibi faaliyetlere (Albayrak, 2013: 156) daha uygun bir bütçe ile katılabilmektelerdir.

Kamp alanları kısa süreli, uzun süreli ve daimî olarak farklı şekillerde kullanilabilirken (Brooker ve Joppe, 2013); transit, rekreasyonel, transit-rekreasyonel ve organizasyon olmak üzere dört gruba ayrllabilmektedir (Öztürk, 2019). Surdu (2014), kampçılığı macera, glamping, tarihsel, kış ve iş olmak üzere beş grupta ifade etmiştir. Macera kampçılığı, muhtemel bisiklet yarışları ve diğer yarışlar gibi temel kamp ekipmanlarının kullanımı ile yürütülen kampçılık türüdür. Tarihsel kampçılık, kamp katılımcılarının tarihte bir döneme özgü ekipmanlar veya yöntemler ile kampa katılmaları ve bunları kullanmaları ile yürütülmektedir. Kış kampçılığı, kış sezonunda yürütülen kampçllı türüdür. Amerikan iş sektöründe hızla büyüyen bir trend olan iş kampçılığı, işverenler tarafından verilen mekân ve ücret ile çalışanlarına iş sonrası bir eğlence tesisi sunduğu kamp türüdür (Surdu, 2014: 13; Birdir, Unur ve Dalg1ç, 2015: 169).

Glamping genellikle 21. yüzyılda henüz yeni bir eğilimi temsil etse de benzer formdaki kökeni çok eskilere dayanmaktadır. Tarihte sosyal statüleri yüksek olan gezginler, sağlam bir konaklama tesisinin olmadığı kalıcı bir ikametgâh dışındaki yerlerde biraz zaman geçirmek zorunda kalmışlardır. Osmanlı İmparatorluğu'nda, padişahlar ve üst düzey yöneticiler kıymetli mobilyalar ve ipek halılar ile sarayı aratmayacak nitelikteki geniş lüks çadırlarda kaldıkları seferlere veya avlara çıkmışlardır. 20. yüzyılın başlarında aristokratların lüks ve konfordan ödün vermeden Afrika safarisinde yaptığı yolculuklar da glamping kavramının çıkış noktasıdır (Petrusa ve Vlahov, 2019: 836).

Doğa temelli rekreatif bir etkinlik olarak konfor ve lüksün birleşiminden oluşan glamping (Lyu, Kim ve Bael, 2020), kampın orijinine aykırı olsa da cazibe ve rahatlık isteyenler için kampın ve konaklama işletmelerinin en iyi unsurlarını birleştiren bir etkinlik olarak talep görmektedir. Aynı zamanda bilinen kamp faaliyetlerinden farklı olarak glamping, büyüleyici dış mekânlarda doğada lüks olarak kabul edilebilecek kral yatağı, klima ve özel banyo gibi imkânlar ile sunulmaktadır (Vrtodusic Hrgovic, 2018). Başka bir deyişle glamping, açık hava deneyimlerindeki rahatsızlıkları ortadan kaldırarak turistlere bir 'açık otel' deneyimi sunmaktadır (Brochado ve Pereira, 2017; Brownne, Jack ve Hitchings, 2019). Glamping, kampın sızan çadırlar, kötü kokulu uyku tulumları ve konserve yiyecekler gibi olumsuzluklarını değiştirmektedir (Boscoboinik ve Bourquard, 2011). Glamping, ağaç evler, safari çadırları, barakalar, soğuğa dayanıklı iglo evler, bungalovlar, şişme odalar gibi farklı şekillerde klasik kamp çadırı algısını değiştirmektedir. Dolayısıyla diğer kamp türlerinden farklı olarak glampingte ana motivasyon lüks ve konfordur (Budiasa, Suparta ve Nurjaya, 2019).

Glamping, doğanın ve lüksün mükemmel birleşimi olarak takdir edilse de; geleneksel kampın otantik değerlerini azalttığına ilişkin eleştirilmektedir (Ahn ve Lee, 2015). Bununla birlikte glamping sadece lüks kampingten çok daha fazlasıdır ve tam olarak 
anlaşılması için bu tür bir konaklama yerinin gelişmesine neden olan niş pazarı ve hedef kitleyi oluşturan "glamperları" bilmek gerekmektedir. Glamper turistler, yoğun çalışma hayatı olan bu nedenle doğanın tadını çıkarmak isteyen ancak otel konaklamasında aldıkları konfordan vazgeçmek istemeyen kişilerdir (CvelicBonifacic, Milohnic ve Cerovic, 2017). Glamperlarm motivasyonu ile glamping yakından ilişkilidir, bu nedenle glamping talebi yenilik ve ürünlerin çeşitlendirilmesi, doğada kalma, lüks ve konfor olmak üzere üç temel açıdan gözlemlenebilmektedir (Petrusa ve Vlahov, 2019: 838). Ayrıca glamperların en önemli özelliği, turist olmayan yerleri ziyaret etmektir.

Öte yandan; lüks ve konfor glamping için ayrılmaz unsurlardır. Glamper turistler, yüksek bir hizmet kalitesi arayan, eğitimli ve bunu bulmak için yüksek fiyat ödemeye gönüllü kişilerdir. Bu turistler maceralı etkinliklerin, zengin yiyecek ve içeceklerin ve diğer imkânların tadını çıkarmak istemektelerdir. Gurme yiyecekler en kaliteli şefler tarafından hazırlanmakta ve turistlerin sadece kişisel eşyalarını getirdiği farklı konseptte çadırların veya mekânların tasarımı ve işlevleri, lüksü ve konforu en üst düzeye çıkarmaktadır. Glamping için lüks, sadece konaklama tesisinin fiziksel özelliklerini değil, aynı zamanda profesyonel kadrosu ve her düzeyde kaliteli hizmeti, kişiselleştirilmiş yaklaşımı ve konuğu özel hissettirecek ilgiyi ifade etmektedir (Sakacova, 2013).

Glamping, niş bir pazar olarak doğa ile özdeşleşmek isteyen, ekonomik bütçe anlamında limiti olmayan kampçılara doğayı ve lüks bir otel konforunu birlikte sunmaktadır. Plastik kaplar yerine porselen tabakların, bahçe hortumu yerine kişiye özel ve açıkta duran tasarım küvetin, tasarım bir mutfağın, İran halılarının ve kuş tüyü yorganların bulunması bu durumu açıklar nitelikte örneklerdir (Ergüven, Yılmaz ve Kutlu, 2015: 260). Özetle, kitle karşıtı, lüks motivasyonlu talep, doğa ile bağlantı, düşük fiyat esnekliği ve mevsimsel karakter glampinge yönelik talebin özellikleridir.

\section{Kapadokya Bölgesi'nin Kamping ve Glamping Açısından Değerlendirilmesi}

Kapadokya, Nevşehir ili merkez olmak üzere Aksaray, Kırşehir, Kayseri ve Niğde illerine uzanan toprakları kapsamaktadır. Bölge, dünyada benzersiz bir jeolojiye sahip, tarih ve kültürel değerleriyle önemli kültür ve inanç turizmi merkezlerinden biridir. Masalsı görüntüsü ve eşsiz doğasıyla dünyanın en büyüleyici atmosferlerinden birine sahip Kapadokya Bölgesi, insanlık tarihi boyunca çok sayıda uygarlı̆̆a ev sahipliği yapmıştır (Nevşehir İl Kültür ve Turizm Müdürlüğü, 2020). Peribacaları gibi ilginç jeolojik yapısının yanı sıra, kayalara oyulan yerleşim yerleri, ender doğal ve kültürel merkezlerdendir. Kapadokya'yı kaplayan yumuşak tüfün kolayca oyulabilmesinden dolayı kayada yaşam biçimi nesiller boyunca devam etmiş, daha sonraki yüzyıllarda inzivaya çekilen keşişler için uygun bir ibadet yeri olmuştur. Farklı büyüklükteki yer altı yerleşimleri daha çok yumuşak tüfün aşağıya doğru derinlemesine oyulmasıyla inşa edilmiştir. Bölgede "Göreme Doğal ve Tarihi Milli Parkı”, 1985 yılında Birleşmiş Milletler Eğitim Bilim ve Kültür Kurumu'nun (UNESCO) Dünya Doğal ve Kültürel Miras listesine girmiştir (Nevşehir Hacı Bektaş Veli Üniversitesi, 2020). Bölgede kültür ve inanç, termal, doğa temelli turizm, kongre ve fuar, gastronomi gibi alternatif turizm 
türlerine ilişkin faaliyetler yürütülmektedir. Bölgede yürütülen turizm türlerinden biri de kamp turizmidir. Kamp turizminin konaklama işletmelerinde sunulan lüks, konfor ve doğanın bütünleştiği glamping turizmi, bölge için yeni bir turizm türüdür. Bu kapsamda Kayalık Kapadokya olarak bilinen Nevşehir ilinin glamping turizmi potansiyeline yönelik değerlendirme (SWOT analizi) Tablo 1'de verilmiştir. Bu değerlendirme, bölgede yürütülen kamp turizmi faaliyetlerinden yola çıkarak yazar tarafından hazırlanmıştır. Tabloda belirtilen SO stratejileri (Strengths Opportunities), güçlü yönleri fırsata çevirmek, WO stratejileri (Weakness Opportunities), zayıf yönleri güçlendirmede fırsatlardan yararlanmak, ST stratejileri (Strengths Threats), tehditlerden kaçınmak amacıyla güçlü yönleri kullanmak ve WT stratejileri (Weaknes Threats) tehditlerden kaçınmada zayıf yönleri en aza indirmek için kullanılmaktadır (Polat, Özdemir ve Özdemir, 2014).

Tablo 1: Kapadokya Bölgesi'nin Glamping Turizmi Potansiyelinin Değerlendirilmesi

\begin{tabular}{ll}
\hline \multicolumn{1}{c}{ Güçlü Yönler (S) } & \multicolumn{1}{c}{ Zayıf Yönler (W) } \\
\hline $\begin{array}{l}\text { Destinasyonda çok uzun zamandır kampçılık ve } \\
\text { karavancılık faaliyetlerinin yürütülmesi, }\end{array}$ & $\begin{array}{l}\text { Destinasyonda glamping turizminin önemi ve } \\
\text { gelişimi hakkında paydaşların bilgi konusunda } \\
\text { yetersizlikleri, }\end{array}$ \\
$\begin{array}{l}\text { Glamping turizmini destekleyebilecek } \\
\text { destinasyonda birçok (atçılık, trekking, tırmanış, } \\
\text { doğa fotoğrafçılığıb.) aktivitenin olması, }\end{array}$ & $\begin{array}{l}\text { Yerel yönetimlerin turizme sadece parasal } \\
\text { kaynak olarak bakması, }\end{array}$ \\
$\begin{array}{l}\text { Destinasyonda turizme ilişkin yerel halkın bakış } \\
\text { açısının olumlu olması, }\end{array}$ & $\begin{array}{l}\text { Gelen yerli ve yabancı konukların bölgede } \\
\text { konaklama günlerinin azlığı, }\end{array}$ \\
$\begin{array}{l}\text { Destinasyonun doğal yapısının glamping turizmi } \\
\text { için uygun olması, }\end{array}$ & Konuyla ilgili akademik çalışmaların azlığı, \\
$\begin{array}{l}\text { Glamperların destinasyonda yaşayabileceği birçok } \\
\text { farklı deneyimin bulunması, }\end{array}$ & \\
\hline
\end{tabular}

\begin{tabular}{|c|c|c|}
\hline Firsatlar & SO Stratejileri & WO Stratejileri \\
\hline $\begin{array}{l}\text { Destinasyona ulaşım } \\
\text { kolaylığı, } \\
\text { Flora ve fauna bakımından } \\
\text { zenginlik, } \\
\text { Destinasyonda on iki aya } \\
\text { yakın turizm faaliyetlerinin } \\
\text { yürütülebilmesi için uygun } \\
\text { bir aktivite olması, }\end{array}$ & $\begin{array}{l}\text { Nevşehir ilinde kültür ve inanç } \\
\text { turizmi uzun süredir } \\
\text { yapılmaktadır. Destinasyona } \\
\text { farklı istekleri olan ve aynı } \\
\text { zamanda harcama gücü yüksek } \\
\text { glamperlara yönelik aktivitelere } \\
\text { uygun iklim ve doğal } \\
\text { güzelliklerin kullanılması için } \\
\text { uygun alanlar yaplabilir. }\end{array}$ & $\begin{array}{l}\text { Nevşehir ilinin yerel yönetimleri ve } \\
\text { sivil toplum kuruluşları glamping } \\
\text { kavramından ve glamping } \\
\text { faaliyetlerinin alternatif bir turistik } \\
\text { ürün olarak kullanımının, yerel halk } \\
\text { ve bölge ekonomisine katkısı } \\
\text { hakkında daha kapsamlı } \\
\text { bilgilendirilmesi ve glamping } \\
\text { turizmini gelişimi için destek } \\
\text { verilmesi sağlanabilir. }\end{array}$ \\
\hline Tehditler & ST Stratejileri & \\
\hline $\begin{array}{l}\text { Glamping turizmi ile } \\
\text { destinasyonda bulunan flora } \\
\text { ve faunanın zarar } \\
\text { görebileceği endişesi, } \\
\text { Destinasyonda glamping } \\
\text { turizminin çok bilinmemesi } \\
\text { veya yanlış bilinmesi, } \\
\text { Destinasyonda geceleme } \\
\text { sayısının azlığı, }\end{array}$ & $\begin{array}{l}\text { Turizm paydaşlarının ve } \\
\text { girişimcilerinin glamping } \\
\text { turizmi konusunda tesis } \\
\text { çeşitlerine ve turist profiline } \\
\text { yönelik bilgilendirilmesi ve } \\
\text { paydaşlar arası iletişim ve } \\
\text { koordinasyon eksikliğinin } \\
\text { giderilmesi yararlı olacaktır. }\end{array}$ & $\begin{array}{l}\text { Nevşehir ili glamping turizmi için } \\
\text { tespit edilen en önemli tehdit olan } \\
\text { flora ve faunanın zarar görmesi } \\
\text { konusunda destinasyonda glamping } \\
\text { turizmi potansiyeline ilişkin } \\
\text { tanıtımlar ile eşzamanlı ortaya } \\
\text { çıkacak doğa farkındalığı ve koruma } \\
\text { anlayışı ile bir bilinç yaratılarak } \\
\text { çözülebilecektir. }\end{array}$ \\
\hline
\end{tabular}

Kaynak: Yazar Tarafından Kamping ve Glamping Turizmi Kapsamında Hazırlanmıştır. 
Nevşehir ili sadece doğal güzellikleri ile değil, aynı zamanda tarihi dokusu ile önemli destinasyonlardan biridir. Ancak farklı istek ve beklentileri olan turistlerin de destinasyona çekilebilmesi için farklı turistik ürünlerin ortaya çıkarılması gerekmektedir. Dolayısıyla glamping turizmi, destinasyonda kültür ve inanç turizmine yönelik turist yoğunluğunu aşabilecek, aynı zamanda destinasyonda geceleme sayısını artırabilecek bir çözüm yolu olabilecektir. Öte yandan kamp ve glamping turizmi, sürdürülebilirlik anlayışı ile eko-turizm odaklı turizm çeşitleridir. Bu nedenle Kapadokya'nın sahip olduğu eşsiz doğal güzelliklerin gelecek nesillere aktarılmasında ve turizm ile bölge ekonomisine katkı sağlanması konusunda kabul edilebilir bir alternatif turizm çeşididir.

\section{YÖNTEM}

$\mathrm{Bu}$ çalışmada, Kapadokya Bölgesi'nin kamp ve karavan turizmi açısından mevcut durumu ortaya koyularak, yeni bir turizm türü olarak glamping turizmi kapsamında bölgede neler yapılabileceği üzerinde durulmuştur. Kapadokya Bölgesi Nevşehir, Aksaray, Niğde, Kayseri ve Kırşehir illerinden oluşmaktadır. Bu çalışma, daha fazla turist çekmesi ve kampçılık faaliyetlerinin yoğun bir şekilde yapılması sebebiyle "Kayalık Kapadokya Bölgesi" olarak adlandırılan Nevşehir ilinde yapılmıştır. Aynı zamanda Nevşehir'in turizm potansiyelinin çantalı gezginler ve karavanlı turistler tarafından keşfedilmesi araştırma alanı olarak tercih edilmiştir. Çalışmada temel araştırma sorusu olarak “Kayalık Kapadokya'da kampçılık faaliyetleri nasıl yürütülmektedir ve bu faaliyetler kapsamında glamping turizmi bölgede nasıl değerlendirilebilir?" şeklinde belirlenmiştir. Bu doğrultuda, Nevşehir' de kampçılık ve karavan turizmi ile ilgili faaliyetleri yürüten işletme yetkililerinin görüşlerinin derinlemesine incelenmesi ve bu işletme yetkililerinin glamping turizmine ilişkin görüşleri alınarak bölgede glamping faaliyetlerinin nasıl değerlendirileceğine ilişkin derinlemesine bilgiler elde edilebilmesi beklenmektedir. Çalışmada, bir tek gerçeklikten ziyade katılımcıların çoklu perspektifine dayanan nitel araştırma yöntemi kullanılmıştır (Creswell, 2013). Araştırma bu yönüyle keşifseldir. Çalışma, görüşme (mülakat) tekniği ile kurgulanmıştır. Görüşme, nitel veri toplam araçlarından biridir. Verilerin toplanması aşamasında yarı yapılandırılmış mülakat yöntemine uygun açık uçlu sorulardan yararlanılmıştır. Bu görüşme türünde araştırmacıya, görüşme öncesinde belirlediği bir dizi soru veya konu başlıkları rehberlik etmektedir (Gürbüz ve Şahin, 2015). Bu kapsamda literatürde araştırma konusu genel hatları ile belirlenmiş ve odaklanılması gereken kısımlar belirlenmiştir (Birdir vd., 2015; Urdal ve Uğurlu, 2016; Göktaş, Çetin ve Kızılırmak, 2017; Olcay ve Turhan, 2017; Salo vd., 2020). Hazırlanan yarı yapılandırılmış görüşme formu farklı alan uzmanları tarafından incelenmiş ve öneriler doğrultusunda forma nihai hali verilmiştir.

Çalışmada kamping ve glamping turizmi açısından Nevşehir' de bulunan beş kamping işletmesi (Nevşehir İl Kültür ve Turizm Müdürlüğü, 2020) ile glampinghub (Glamping, 2020) sitesinde Kapadokya Bölgesi'nden kayıtlı olan bir otel işletmesi olduğu tespit edilmiştir. Görüşmelerde tam sayım elde edilmesi için kaynak kişi olacak bu işletmelere öncelikle bir bilgilendirme yazılarak ön görüşme talebi için 
iletişime geçilmiştir. Ancak "glampinghub" sitesine kayıtlı işletme olumlu cevap vermediği için çalışma kapsamına dâhil edilmemiştir. Bu kapsamda çalışmada tamsayım yapılmış denilebilir. Öte yandan nitel araştırmalarda genelleme kaygısının güdülmediği bir diğer gerçektir. Nitel araştırmalarda bilindiği gibi, örneklemin temsil edicilikten ziyade orijinalliği önem taşımaktadır. Nitel araştırmaların az sayıda katılımcı ile daha derinlemesine, konunun çeşitli yönlerle ele alınması en önemli tercih sebebidir (Kincal, 2010: 62).

Olumlu geri dönüş yapan kamping işletmelerine çalışmanın amacı ve içeriğinden bahsedilmiş, gönüllük esası ile isimlerinin gizli kalacağı konusunda bilgi verilmiştir. Bu görüşme sonucunda katılımcılara görüşme talebinde bulunulmuştur. Kabul eden işletmeler belirlendikten sonra bir görüşme listesi oluşturulmuştur. Bununla birlikte çalışmanın uygulanabilmesi için gerekli olan etik kurul izni alınmış (Bu çalışmanın Nevşehir Hacı Bektaş Veli Üniversitesi Sosyal ve Beşerî Bilimler Araştırmaları Etik Kurulu Yönergesinde belirtilmiş Etik İlkelere uygun olduğuna karar verilmiştir. Karar tarih:23.10.2020 Karar Numara: 2020.19.266) ve buna göre işletme yetkilileri ile 25 Ekim-1 Kasım 2020 tarihleri arasında görüşmeler gerçekleştirilmiştir.

Görüşmelerde katılımcılara ilk olarak çalışmanın içeriği ve amacı hakkında bilgi verilmiş ve buna istinaden izin alınmıştır. Görüşmeler ses kayıt cihazı vasıtasıyla kayıt altına alınmış ve ayrıca görüşme esnasından ayrıntı olabileceği düşünülen notlar tutulmuştur. Katılımcılarla beş ifadeden oluşan yarı yapılandırılmış görüşme formu doğrultusunda görüşülmüştür. Çalışmanın veri toplama süreci COVID-19 pandemi esnasında yapılması nedeniyle konu ile ilgili Bakanlıkların belirttiği sosyal mesafe ve maske kurallarına uyularak işletmelerin belirlediği açık alanda yüz yüze görüşülmüştür. Katılımcıların ifadelerine göre gerektiğinde ek sorular da sorulmuştur. Yapılan görüşmeler ortalama 20 ila 30 dakika arasında sürmüştür. Araştırmacı, yapılan görüşme kayıtlarını öncellikle yazılı hale getirmiş, farklı kayıtmetin kayıtları dinlenerek karşılıklı kontroller yapılmıştır. Bu doğrultuda elde edilen verilere içerik analizi uygulanmıştır.

\section{BULGULAR}

Çalışmanın bu kısmında, araştırmaya katılan katılımcılara ilişkin demografik bilgilere ve görüşme esnasında verilen bilgilere ilişkin bulgulara yer verilmiştir.

\section{Katılımcılara ve İşletmelere İlişkin Bulgular}

Çalışmaya katılmayı kabul eden beş katılımcıya görüşmede öncelikle kendilerini tanıtmaları istenmiştir. Buna göre katılımcıların cinsiyet, yaş, eğitim düzeyi, sektör deneyim süresi, işletmedeki deneyim süresi ve işletmedeki pozisyon şekli gibi demografik bilgilerine ilişkin sorular yöneltilmiştir. Katılımcıların \%20'si kadındır. Bunun nedeni olarak Kapadokya Bölgesi'nin İç Anadolu Bölgesi'nde yer alması ve bu bölgede ağırlıklı olarak ataerkil bir sistemin hâkim olmasıdır. Katılımcıların eğitim düzeylerine göre \%20'si lisans mezunudur ve bu katılımcı işletme konusunda eğitim almıştır. Katılımcıların büyük çoğunluğu (\%60) ise lise mezunudur. Bunun nedeni 
olarak katılımcılar tarafından iş hayatına başlamayı tercih ettikleri bildirilmiştir. Katılımcıların diğer demografik bilgileri ise Tablo 2' de verilmiştir.

Tablo 2: Katılımcı İşletmelerin Genel Bilgileri

\begin{tabular}{|c|c|c|c|c|c|c|}
\hline Katılımcilar & $\begin{array}{l}\text { İşletme } \\
\text { Açılış } \\
\text { Yılları }\end{array}$ & Yaş & $\begin{array}{l}\text { Turizm } \\
\text { Deneyimi }\end{array}$ & $\begin{array}{l}\text { İş Deneyimi } \\
\left(Y_{1} l\right)\end{array}$ & $\begin{array}{l}\text { İşletmede } \\
\text { Deneyimi } \\
\left(Y_{11}\right)\end{array}$ & İşletme Pozisyonu \\
\hline K1 & 1994 & 40 & Evet & 15 & 5 & İşletmeci \\
\hline K2 & 1979 & 39 & Evet & 25 & 9 & İşletmeci \\
\hline K3 & 1985 & 48 & Evet & 20 & 15 & $\begin{array}{l}\text { Muhasebe } \\
\text { Müdürü }\end{array}$ \\
\hline K4 & 2018 & 42 & Evet & 20 & 3 & Genel Müdür \\
\hline K5 & 1990 & 60 & Evet & 45 & 45 & İşletmeci \\
\hline
\end{tabular}

Katılımcıların yaşları incelendiğinde; büyük çoğunluğu orta yaş grubunda yer almaktadır. Katılımcıların çoğunluğu işletmede bulundukları pozisyonları bakımından kira karşılığı kamp alanının işletmeciliğini yapmaktadırlar. Katılımcıların sadece biri işletmenin sahibidir. Katılımcılardan K5'in işletme deneyimi diğerlerinden daha fazladır. Bunun nedeni, Kapadokya Bölgesi'nde kampçılık hizmeti veren ilk işletmecilerden olmasıdır. Katılımcıların hepsi iş deneyimi olarak birçok turizm işletmesinde farklı pozisyonlarda görev almıştır.

Katılımcılara işletmelerinin kuruluşu hakkında bilgi vermeleri istendiğinde, işletmelerin birçoğu çok eski işletmeler olduğu ancak bazı sebeplerden isim değişiklikleri yaptıklarını ve bu nedenle faaliyet yılında farklılıklar olduğunu belirtmişlerdir. Ayrıca katılımcılar, bölgedeki turistlerin ihtiyaçları doğrultusunda işletmelerin kendi girişimleri ile açıldıkları ve yabancı ziyaretçiler tarafından ilgi gördükleri yönünde olduğunu ifade etmişlerdir. Katılımcılar işletmelerinde temel hizmetlerin verildiğini ifade etseler de K2, K4 ve K5 no.lu katılımcılar konaklama, yeme-içme dışında havuz, bölgeye özgü gezi turları ve atv, atlı safari turlarını da isteğe bağlı olarak düzenlediklerini bildirmiştir. Katılımcılar, çadırı veya karavanı ile gelen turistlere uygun yer verdiklerini, bununla birlikte işletmeye çadırsız gelen misafirler için kışlık ve yazlık olmak üzere farklı nitelikte çadırlar olduğunu da belirtmişlerdir.

Katılımcılara işletmelerinin herhangi bir kuruluşa veya derneğe üyeliği ile ilgili soru yöneltildiğinde, birçok farklı derneğe ve kuruluşa üyelikleri olduğu öğrenilmiştir. K4 no.lu katılımcı "İşletmemiz Türkiye Kamp ve Karavan Derneği'ne üyedir. Aynı zamanda işletmemiz, bölgede çeşitli kamp ve karavan kulüplerinin toplantı mekânları olarak hizmet vermektedir. Bu toplantılara da üye olarak aktif katılım gösteriyoruz." şeklinde cevap vermiştir.

\section{İşletme Mevcut Durumu}

Tüm katılımcılar 2020 yılı öncesinde işletmelerinin doluluk oranının \%70 üzeri olduğunu ve gelen misafirlerin en az iki ile yedi gün arasında konakladıklarını bildirmiştir. Aynı zamanda K1 ve K3 no.lu işletmeler dişında diğer kamping işletmeleri tüm yıl boyunca faaliyetlerini sürdürdüklerini de ifade etmişlerdir. K1 ve 
K3 no.lu katılımcıların işletmeleri sezonluk çalışmaktadır. Öte yandan 2020 yılı, K5 no.lu katılımcı tarafından "Kapadokya Bölgesi'nde turizm açısından ciddi yoğunluğun ve iş akışının yaşandığ1 bir dönemden dibi görüştür" olarak nitelendirilmiştir.

2020 yılında yaşanan COVID-19 süreci ve yurtiçi ve yurtdışı seyahat kısıtlamaları ve diğer çeşitli sınırlılıklar nedeniyle turizmin bölgede bitme noktasına geldiği ve bu hususun turizm sektöründe endişe yarattığı bir gerçektir. Kapadokya Bölgesi birçok krizi atlatmış ve bu konularda deneyim kazanmış olsa da COVID-19 pandemisi gibi dünya çapında her şeyi durma noktasına getirmiş bir konuda sektörün hassas dengelerinin nasıl düzeleceği ve tekrar nasıl ivme kazanacağı belirsizdir. Bu doğrultuda, katılımcıların her biri endişeli ve süreci nasıl yönetecekleri konusunda kararsızdır. 2020 yılında doluluk oranı olarak belirtilen oran \%10-\%20 şeklindedir (Acar, 2020). Bu oran ise katılımcılar tarafindan kamp misafirlerinin çoğunluğunun turizm işletmelerinde yaşanabilecek hijyen sorunları ve etkileşime bağlı riskler nedeniyle kamping işletmelerini tercih ettikleri şeklinde ifade edilmiştir. Bu kapsamda bölge turizm işletmelerinin yaşanabilecek değişimlere ve yeniliklere uyum sağlaması gerekmektedir. Kapadokya Bölgesi'nde faaliyet gösteren kamping işletmelerinin bu süreçte tek başına ayakta durabilmesi mümkün gözükmemektedir. Bu nedenle işletmelerin daha az zarar ile bu süreci atlatabilmesinde vergi borçlarının ertelenmesi veya indirim görmesi, devletin turizm işletmelerine yönelik yatırım teşvikleri ve destek kredileri oluşturması gibi faaliyetlerinin devamında etkili olan ekonomik sorunlara yönelik desteğe ihtiyaç vardır.

\section{Arz ve Talep Durumu}

Katılımcılara rakiplerinin kim olduğuna ve bu rakiplerden farklı özelliklerine ilişkin sorular yöneltilmiştir. Katılımcıların büyük çoğunluğu kendilerine en büyük rakiplerin bölgede faaliyet gösteren kaya otel ile dört ve beş yıldızlı otel işletmelerinin olduğunu ifade etmiştir. K1 no.lu katılımc1 "Kamping yapan işletmeler birbirine rakip değil, en önemli destekçilerdir." diye fikrini ifade etmiştir. Katılımcılar bu rakiplerden farklı olarak doğayı kullandıklarını, standart hizmetler dışında kendi halinde kalabalıklardan uzaklaşmak, zindeleşmek isteyen maceraperest turistlere hizmet sunduklarını dile getirmişlerdir.

Katılımcılara yerli/yabancı turistlerden ağırlıklı olarak hangisi ile çalıştıklarına ilişkin soru yöneltildiğinde, K2 no.lu katılımc1 “Kamp hayatını Avrupalı turist, yaşam tarzı olarak benimsemiştir. Kapadokya sevgileri belki de doğa ile bütünleşebildikleri kampinglerle katmerleşiyordur." diye ifade etmiştir. K4 no.lu katılımcı ise "Yerli ve yabancı turistlere hitap ediyoruz. Türkiye' den daha çok büyükşehirlerde yaşayan yerli turistler gelirken; yabancı olarak Avrupalı turistlerden özellikle Alman ve Fransız turistler gelmekte ve son yillarda Kuzey Avrupalı turistler de kamp ve karavan turizmi kapsamında bölgeye gelmeye başladı." şeklinde cevaplamıştır.

K5 no.lu katılımcı kamp ve karavan turistleri için “Kamp ve karavana meraklı yabancı turistler genellikle eğitimli, Türkiye'de kıyı bölgeleri gezmiş, Kapadokya'nın güzelliklerini ve tarihini de bazen kendi ülkesinden karavanı veya çadırı ile gelen 
bazen de kiraladığı karavanla kampinglerde bulunan bungalov veya çadırlarda konaklayarak tatil deneyimini yaşayan orta ve üst gelir düzeyine sahip maceraperest kişilerdir." diye tanımlamıştır. K3 no.lu katılımcı "Kendi karavanı veya çadırı ile bölgede uzun süre konaklamak için gelen düşük veya orta düzey eğitimli doğasever kişilerdir. Misafirlerin gelir düzeyi kampinglerde sorulmaz. Kimi zaman üst gelire sahip bir misafir son model bir karavanla bölgede kamping işletmelerinde konakliyor. $\mathrm{Bu}$ nedenle kamp ve karavan turizmi için genel bir profil oluşturmak zordur. Kamp ve karavan bir yaşam tarzıdır." şeklinde belirtmiştir. Bu ifadelerle kamp ve karavan turistlerinin profilinin net olmadığını ancak temelde macera ve doğa düşkünü, eğitimli kişiler olduğu vurgulanmıştır.

\section{Glamping Turizmi Hakkında Görüşler}

Katılımcılara görüşme esnasında glamping kavramından ve bu yeni turizm türünün avantajlarından ve dezavantajlarından bahsedilmiştir. Ardından katılımcılara glamping kavramını daha önce duyup duymadıkları, duydularsa konu hakkında ne düşündükleri ve Türkiye'de glamping turizminin nerelerde daha uygun yapılabileceğine ilişkin sorular yöneltilmiştir. Glamping kavramını katılımcıların büyük bir çoğunluğu duymadığını, katılımcılardan biri misafirlerinden biriyle yaptığı sohbette öğrendiğini ve araştırdığını, bir diğer katılımcı da üye olduğu turizm platformunda duyduğunu belirtmiştir. Konuyla ilgili olarak K1 no.lu katılımcı "Gelen misafirlerle sohbet etmeyi severim. Bu sohbetlerden birinde misafir bana işletmemi glamping işletmesi olarak yeniden düzenlemem gerektiğini ve böylece daha fazla kar elde edebileceğimi anlattı. Araştırdım, işletmeye çok uygun bir trend ancak; bu durumda fiyatları yükseltmemiz gerektiği ve artık alt veya orta gelirli misafirleri işletmeye kabul edemeyeceğimiz düşüncesi ile vazgeçtim. İşletme anlayışımız bir sınıf veya zümreye hizmet değildir. Tatil yapmak ve doğa ile buluşmak isteyen tüm misafirlere uygun hizmet vermektir." şeklinde glamping kavramını bildiğini dile getirmiştir. Bu ifade ile kamping işletmelerinin temelde verdikleri hizmetin glamping turizmi için uygun olduğunu ancak hizmette yapılacak değişikliklerin lüks sıfatı ile işletme anlayışından uzaklaşılacağı ortaya koyulmuştur. Ayrıca, Kapadokya Bölgesi için uygun bir turizm türü olan glamping konusunda işletmelerin daha fazla bilgiye ihtiyacı olduğu ve bu açıdan işletmelerin bakış açılarının değişebilmesi için örneklerin gösterilerek avantaj/dezavantajlarının ortaya koyulması gerekmektedir.

Katılımcılara Türkiye'de glamping turizmi için elverişli bölgelere ilişkin soru yöneltildiğinde katılımcılardan K3, "Kapadokya eşsiz güzelliği ile glamping turizmine yönelik işletmeler için uygun bir bölge. Kaya oteller belki glamping kapsamında sayılabilir ancak glamping kavramına ilişkin bir standart ve ilerleme planı oluşturulursa daha istikrarlı bir gelişim yaşanır. Ülkemizin her yeri değerli, örneğin Antalya'nın her şey dâhile kurban gitmemesi için alternatif çözüm yolları aranmalıdır. Glamping bu anlamda desteklenmesi gereken bir oluşum olabilir. Glamping, devlet kredileri ve kalkınma ajanslarının açılış bilgilendirme destekleri ile turizme yeni bir anlayış getirebilir." şeklinde cevaplamıştır. Bu ifade ile aslında Türkiye'nin sahip 
olduğu turizm anlayışının değiştirilmesi gerektiği konusunda hem fikir olunduğu ancak bu değişimin nasıl ve ne şekilde olacağının belirsiz olduğu açıklanmaktadır.

\section{İşletme ve Sürdürülebilirlik İlişkisi}

Turizm sektörünün en önemli cazibe unsurlarından biri hiç şüphesiz doğal güzelliklerdir. Doğal güzellikleri kaynak olarak kullanan turistik destinasyonların ve işletmelerin sürdürülebilirlik anlayışını benimsemesi ve sahip olunan değerlerin gelecek nesillere aktarılması şarttır. Bu kapsamda katılımcılara işletmelerinin sürdürülebilirlik kapsamında neler yaptıklarını, kamping ve glamping işletmelerinin sürdürülebilir turizm kapsamında değerlendirilip değerlendirilemeyeceği ve yerel halk katılımına ilişkin işletmelerinin tutumu hakkında sorular yöneltilmiştir.

Katılımcılar, kamping ve glamping işletmelerinin temel çıkış noktalarının doğa ile buluşma olması sebebiyle sürdürülebilir olabilmesi için doğaya sahip çıkılması gerektiğinin ve gelecek nesillere korunaklı bir şekilde sahip olan değerlerin bırakılması gerektiği konusunda hemfikirdir. Aynı zamanda katılımcılar, işletmelerinde mümkün olduğunca doğa dostu bir yaklaşım izlediklerini belirtmişlerdir. K4 no.lu katılımcı konu hakkında "İşletmemizde işletme içi yazışmalar e-posta olarak yapılırken, personel bilgilendirmeleri ve misafir belgeleri için müsvedde kâğıtlar kullanılır. Mutfak kısmında olabildiğince tekrar kullanılabilir malzemeler tercih edilmektedir. Misafirlerin kullandıkları genel alanlarda su ve atık yönetimine ilişkin bilgilendirmeler vardır. Aynı zamanda kamp alanının sulanmasında atık suları kullanıyoruz." şeklinde işletmesine ait çevre dostu uygulamalardan bahsetmiştir. Aynı konuya ilişkin olarak K5 no.lu katılımcı "işletmemizde atıkların ayrıştırılmasını kolaylaştıran hazneler var. Bunlar anlaşmalı bir geri dönüşüm firması tarafından haftalık olarak alınır. Ortak alanlarda sabun, şampuan gibi malzemeler doldurulabilir tercih ediliyor. Aynı zamanda misafirlerimiz ile bölgede çöp toplam etkinlikleri yapıyoruz. Bunlara katılmak isteyen halkı da dâhil ediyoruz. Bir anlamda doğaya bize verdikleri için teşekkür ederken; ona kötü davrananlar için özür diliyoruz." diye ifade etmiştir.

Alan yönetimi kamping ve glamping işletmeleri için önemli bir konudur. Sürdürülebilir bir işletme anlayışı için çevre düzenlemelerine dikkat edilmelidir. Bu konuda K1 no.lu katılımcı "Kamping alanında peyzaj çalışmaları yapıyoruz ve bölge iklimine uygun ağaçları dikerek mümkün olduğunca alanımızı korumaya çalışıyoruz. Bunun dışında kampçıların yiyebilmesi için bölgenin meşhur asmalarını ve meyve ağaçlarını yetiştirmeye çalışıyoruz. Misafirlerimiz yemek için mevsimine göre buradan istedikleri kadar meyve toplayabiliyorlar. Yaz aylarında şemsiyeler bahçemizde bulunuyor ancak onları da olabildiğince görüntü kirliliği yaratmaması için ahşap veya çadırlarla aynı renk kumaştan tercih ediyoruz." diyerek çalışmalarını özetlemiştir. Bununla birlikte K3 no.lu katılımcı "İşletmede yapılan peyzaj çalışmaları dışında isteyen misafirlerimize fidan satışımız vardır. Böylece bölgede bir dikili ağaçları olduğunu ve doğaya katkıda bulunduklarını düşünmelerini istiyoruz." demiştir. 
Katılımcılar sürdürülebilirlik kapsamında işletme-yerel halk katılımına özen gösterdiklerini, çalışanları bölge halkından niteliklerine uygun olarak tercih ettiklerini ve her birine kampçılık ve mahremiyet hakkında işbaşı eğitim verdiklerini belirtmişlerdir. Bunun yanı sıra soruya ilişkin olarak K2 no.lu katılımcı "İşletmemizde kahvaltı isteyen misafirlere kahvaltı hizmeti de veriyoruz. Kahvaltıda kullanılan ürünlerin hemen hepsi yöresel ürünlerdir ve bu ürünleri yerel halktan satın alıyoruz. İşletme ofisimizde bir yöresel ürünler standı var. Bu stantta, yöre kadınlarının el emeği ürettiği ürünleri misafirlere sunuyoruz ve onları bir anlamda misafirlerimiz ile buluşturuyoruz." diyerek işletmenin yerel halka ilişkin tutumunu ortaya koymuştur.

\section{TARTIŞMA, SONUÇ VE ÖNERİLER}

Post-modern toplumlarda insanların üzerindeki sorumluluklar ve buna bağlı stres artmaktadır. İnsanlar birkaç günlüğüne bile olsa stres ve sorumluluklarından kurtulabilmek, zinde olmak ve boş zamanlarını değerlendirmek için turizm faaliyetlerine katılmaktadır. Doğa temelli alternatif turizm çeşitlerden biri olan kamp turizmi, doğada rekreatif veya sportif etkinliklerde bulunmak, belirli bir süre konaklamak, dinlenmek gibi amaçlarla çadır, karavan, bungalov ve karavan tarzı konaklama olanakları ile gerçekleştirilen turizm faaliyetlerini kapsamaktadır. Kamp işletmeleri, diğer konaklama işletmelerinden farklı olarak konaklama ve yeme-içme, eğlence faaliyetlerini katılımcılara daha ulaşılabilir olarak sunmaktadır.

Öte yandan kampçılığın daha az gelir seviyesine sahip insanlara sunulan bir imkân gibi düşünülmesi, üst gelir seviyesine sahip turistlerin de bu olanaklardan nasıl faydalanabileceklerini gündeme getirmiştir. Kamp alanlarındaki yenilikçi bir konaklama şekli olan glamping, kalitenin ve rekabetçiliğin artırılmasına yönelik yeni bir stratejik değişim yaratmaktadır. Lüks ve kampçılığı bir araya getiren glamping, bilinen kamp faaliyetlerinden farklı olarak büyüleyici dış mekânlarda doğada lüks olarak kabul edilebilecek olanakları birleştirmektedir.

Çalışmada, Kapadokya Bölgesi'nin kamp ve karavan turizmi açısından mevcut durumu ortaya koyularak, yeni bir turizm türü olarak glamping turizmi kapsamında bölgede neler yapılabileceğine ilişkin öneriler sunmak amaçlanmıştır. Bu doğrultuda, Kayalık Kapadokya olarak bilinen Nevşehir ilinde yer alan beş kamp işletmesi ve bir glampinghub sitesinde üyeliği bulunan bir otel işletmesi çalışma alanı olarak kabul edilmiştir. Yapılan görüşmeler sonucu olumsuz dönüş yapan otel işletmesi çalışma kapsamına dâhil edilmemiştir. Çalışmada nitel veri toplam araçlarından biri olan görüşme (mülakat) tekniği kullanılmıştır. Verilerin toplanmasında yarı yapılandırılmış mülakat yöntemine uygun açık uçlu sorulardan yararlanılmıştır.

Yapılan görüşmeler sonucunda katılımcıların glamping turizmi konusunda çok bilgili olmadıkları ortaya koyulmuştur. Öte yandan glamping turizmi hakkında bilgi verildiğinde turizm sektöründe bölgeyi girişimcilik açısından kullanılabilir buldukları, literatürü destekler niteliktedir (Göktaş ve Kızılırmak, 2017). Çalışmada katılımcı işletmelerin kamp alanlarında temel hizmetleri verdiği, az bir çoğunluğun bu ihtiyaçlara ek olarak misafirlerine bölgede yapılacak aktiviteler sunduğu vurgulanmıştır. Elde edilen bu bulgu, kamp işletmelerinin glamping işletmelerine 
dönüşebilmesinde temel ihtiyaçların ötesine geçmelerinin gereği ortaya konmuştur (Brooker ve Joppe, 2013; Ergüven vd., 2015; Brochado ve Pereira, 2017; Salo vd., 2020). Çalışma sonuçlarına göre, Kapadokya Bölgesi'nin kamp turizmi açısından önemli bir bilinirliğinin olduğuna ve mevcut kamping işletmelerinin hizmetlerinde kalite düzeylerini artırmaları ile bölgenin kamping destinasyonu imajından glamping için de alternatif bir destinasyon olabileceğine ulaşılmıştır.

Çalışmanın bir diğer sonucu da katılan işletmelerin sürdürülebilir bir işletme anlayışına sahip olduğudur. İşletmeler bu anlayışla kamp alanlarında alan yönetimini yürütmektedir. Aynı zamanda işletmeler, yerel halka saygılı ve onları turizmle birleştirme noktasında aracı rolünü üstlenmiştir. Çalışmada elde edilen diğer önemli bir bulgu ise katılımc1 profili ile ilgili bulgudur. Katılımcılar kamp turistlerinin profillerine ilişkin olarak net bir bilgi vermenin zor olduğunu; bakıldığında özellikle eğitimli ve her gelir seviyesinden kişinin doğa sevgisi ile kamp alanlarına geldiğini belirtmektelerdir. Kampçılık yapmak isteyen ancak kendi çadırı, tulumu gibi eşyaları getirmek istemeyen ve bir konaklama işletmesinde bulduğu konforu arayan turistler, farklı arayış içindedir. Dolayısıyla bölgede glamping, çok bilinmeyen ve alternatif bir turistik ürün olarak kullanılabilecek bir potansiyeldedir. Bu bulgular yerli ve yabancı literatürde daha önce yapılan çalışmaların sonuçlarını destekler niteliktedir (Birdir vd., 2015; Göktaş vd., 2017; Vrtodušić Hrgović vd., 2018; Brochado ve Brochado, 2019).

Glamping turizminin Kapadokya Bölgesi'nde geliştirilmesinde, iş birliği ve koordinasyon oluşturulmalı ve bu turizm çeşidinin sektörde yeni bir işkolu açmasında cazip hale getirilmelidir. Ayrıca glamping turizmin çıkış noktasının doğa olması sebebiyle bölgenin sahip olduğu değerlerin korunarak gelecek nesillere aktarılması konusunda bölge sektör temsilcilerine ve yerel halkına bilinç kazandırılmalıdır. Aynı zamanda glamping turizminin girişimcinin ve bölgenin kalkınmasına yardımcı olabilmesi konusunda kamu ve bölge kalkınma ajanslarına büyük iş düşmektedir.

Çalışmanın birtakım sınırlılıklara sahip olduğu da göz ardı edilmemelidir. İlk olarak, çalışma Kayalık Kapadokya olarak bilinen Nevşehir ilinde yapılmıştır. Nevşehir'de kamping işletmelerinin sınırlı olması nedeniyle çalışmanın nicel yöntemlerle yapılmasını zorlaştırmıştır. Bu kapsamda çalışmada derinlemesine konuya değinebilmek için nitel veri toplama yöntemlerinden görüşme kullanılmıştır. Bununla birlikte, COVID-19 pandemi sürecinde zarar gören sektörlerin başında turizm endüstrisi gelmektedir. Bu nedenle katılımcı işletmelerin sektörün daralmaya gittiğine yönelik kaygı ve ümitsizliği görüşmede yer alan ifadelere yansımıştır. Dolayısıyla çalışmanın sektörün yoğun olduğu bir zamanda yapılması, elde edilen verilerin değişebileceğini düşündürmektedir. Aynı zamanda Kapadokya Bölgesi'nde turizmin başlamasında kamp ve karavan faaliyetleri önem taşımaktadır. Ancak konuya ilişkin literatürde yer alan çalışmaların sınırlı olması da bir diğer kısıttır.

$\mathrm{Bu}$ kapsamda gelecek çalışmalara yönelik bazı öneriler sunulabilir. Gelecek çalışmalarda kamp turizmi açısından Türkiye'nin ve her bölgenin mevcut konumu ve sorunları irdelenerek kamp alanlarının glamping turizmi kapsamında kullanılmasına ilişkin bir model önerilmesi yol gösterici olacaktır. Aynı zamanda çalışmada elde 
edilen konuya ilişkin derinlemesine bilginin nicel veya karma yöntemlerle irdelenmesi yerinde olacaktır. Bununla birlikte, Türkiye'de glamping işletmelerine gelen misafirlerin fikirleri ve işletmelerden memnuniyetleri de yaşadıkları deneyim açısından önemlidir. Bu doğrultuda daha sonraki çalışmalarda gelen yabancı misafirlerin milliyetlerine göre alternatif turizm türü olarak glamping turizminin Türkiye'de kullanılabileceği irdelenmelidir. Bununla birlikte glamperların memnuniyetlerinin ölçülmesi de yeni bir turizm çeşidi olan glamping turizminin geliştirilmesine bir boyut kazandıracağı düşünülmektedir.

Hakem Değerlendirmesi: Dis, bağmsiz.

Teşekkür: Katkılarından dolayı hakemlere teşekkür ederim.

Destek Bilgisi: Herhangi bir kurum ve/veya kuruluştan destek alınmamıştır.

Çıkar Çatışması: Çıkar çatışması yoktur.

Etik Onayı: Bu çalışmanın tüm hazırlanma süreçlerinde etik kurallara riayet edildiğini yazar(lar) beyan eder. Aksi bir durumun tespiti halinde Güncel Turizm Araştırmaları
Dergisi'nin hiçbir sorumluluğu olmayıp, tüm sorumluluk makale yazar(lar)ina aittir.

Bilgilendirilmiş Onam Formu: Tüm taraflar kendi rızaları ile çalışmaya dâhil olmuşlardır.

Etik Kurul Onayı: Nevşehir Hacı Bektaş Veli Üniversitesi etik kurulu onay tarihi: 23.10.2020 ve karar numarası: 2020.19.266

Araştırmacıların Katkı Oranı: 1. yazar katkı oranı: \%100.

Veri Kullanılabilirlik Beyanı: Araştırma verileri paylaşılmamıştır.

\section{KAYNAKÇA}

Acar, Y. (2020). Yeni koronavirüs (Covıd-19) salgını ve turizm faaliyetlerine etkisi. Güncel Turizm Araştırmaları Dergisi, 4(1), 7-21.

Ahn, C, S. ve Lee, M. S. W. (2015). Adventure campers, fairy tale glampers, and authenticity, tourism engagement, pesonen. J. Komppula, (Eds), Tourism engagement: co-creating well-being, Proceedings of the 6th Advances in Tourism Marketing Conference, (ss. 1217), Finland: Joensuu.

Albayrak, A. (2013). Alternatif turizm. Ankara: Detay Yayıncılık.

Anderson, C. V. (1979). Camping history. W. C. Graendorf and L. D. Mattson (Eds.), Introduction to christian camping (pp. 33-47), Chicago, IL: Moody Press.

Birdir, K., Unur, K. ve Dalgıç, A. (2015). Türkiye'de ve Dünya'da Kamping ve Yeni Bir Turistik Ürün Olarak Glamping. 1. Eurasia International Tourism Congress: Current Issues, Trends and Indicators, 28-30 May1s, Konya, (ss. 168-177).

Brownne, A. L., Jack, T. ve Hitchings, R. (2019). Already existing' sustainability experiments: lessons on water demand, cleanliness practices and climate adaptation from the UK Camping Music Festival. Geoforum, 103, 16-25, https://doi.org/10.1016/j.geoforum.2019.01.021.

Cvelić-Bonifačić, J., Milohnić, I., ve Cerović, Z. (2017). Glamping-creative accommodation in camping resorts: insights and opportunities. ToSEE-Tourism in Southern and Eastern Europe, 4, 101-114. 
Borrie, W.T., ve RoggenbucK, J.W. (2001). The dynamic, emergent, and multi-phasic nature of on-site wilderness experiences. Journal of Leisure Research, 33(2), 202-228.

Boscoboinik, A. ve Bourquard, E. (2011). Glamping and rural imagery. H. Horáková, ve A.Boscoboinik (Eds.), From production to consumption: transformation of rural communities, Zurich: LIT Verlag.

Brochado, A. ve Brochado, F. (2019). What makes a glamping experience great?. Journal of Hospitality and Tourism Technology, 10(1), 15-27.

Brochado, A. ve Pereira, C. (2017), Comfortable experiences in nature accommodation: perceived service quality in glamping. Journal Of Outdoor Recreation And Tourism, $17,77-83$.

Brooker, E. ve Joppe, M. (2013). Trends in camping and outdoor hospitality-an international review. Journal of Outdoor Recreation and Tourism, 3, 1-6.

Budiasa, M., Suparta, K. ve Nurjaya, W. (2019). Implementation of green tourism concept on glamping tourism in Bali. Advances in Social Science, Education and Humanities Research, 354, 210-214.

Creswell, J. W. (2013). Nitel Araştırma Yöntemleri: Beş Yaklaşıma Göre Nitel Araştırma ve Araştırma Deseni. Ankara: Siyasal Kitabevi.

Ergüven, M. H., Yılmaz, Ö. G. A. ve Kutlu, Ö. G. D. (2015). Turistik ürün çeşitlendirme bağlamında hibrit turizm: glamping örneği. The Journal of Academic Social Science Studies, 41, 255-265.

Glamping, (2020). Glamping List in Turkey. Erişim Adresi: https://glampinghub.com/turkey/?checkin=\&checkout=\&adults=2\&children=0\&infant $\mathrm{s}=0$ \&lang=en\&page $=1 \&$ sort $=$ recomended\&currency $=\mathrm{USD} \&$ boundingBox $=\{\% 22$ northE ast $\% 22:\{\% 22$ lat $\% 22: 41.00175435636892, \% 22 \operatorname{lng} \% 22: 38.607726415801395\}, \% 22$ southWe st\%22: $\{\% 22$ lat $\% 22: 26.869510059895116, \% 22 \operatorname{lng} \% 22: 29.35086520593201\}\} \&$ filters $=\{\% 22 \mathrm{c}$ ategories\%22:[],\%22features\%22:[],\%22flags\%22:[],\%22genericCollection\%22:\%22Aut oCollection-12183\%22\} (22.09.2020).

Göktaş, L. S., Çetin, G. ve Kızılırmak, İ. (2017). Özel ilgi turizmi olarak glamping turizminin mevcut durumu: Bir örnek olay analizi araştırması. 4. Disiplinlerarası Turizm Araştırmaları Kongresi, 9-12 Kasım, Kuşadası, Aydın, (s.107-120).

Gürbüz, S. ve Şahin, F. (2015). Sosyal Bilimlerde Araştırma Yöntemleri, Felsefe-YöntemAnaliz. Ankara: Seçkin Yayıncılık.

Gürsoy, D. ve Chen, B.T. (2012) Factors influencing camping behavior: The case of Taiwan. Journal of Hospitality Marketing \& Management, 21(6), 659-678.

Hardy, A., Hanson, D. ve Gretzel, U. (2012). Online representations of RVing neotribes in the USA and Australia. Journal of Tourism and Cultural Change, 10(3), 219-232. DOI: http://dx.doi.org/10.1080/14766825.2012.667415.

Hassell, S., Moore, S. A. ve Macbeth, J. (2015) Exploring the motivations, experiences and meanings of camping in national parks. Leisure Sciences, 37(3), 269-287, https://doi.org/10.1080/01490400.2014.995325. 
Hewer, M. J., Scott, D. J. ve Gough, W. A. (2017). Differences in the importance of weather and weather-based decisions among campers in Ontario Parks (Canada). International Journal of Biometeorol, 61(10), 1805-1818.

Hitchings, R., Browne, A. ve Jack, T. (2018). Should there be more showers at the summer music festival? Studying the contextual dependence of resource consuming conventions and lessons for sustainable tourism. Journal of Sustainable Tourism, 26(3), 496-514.

Kıncal, R. Y. (2010). Bilimsel Araştırma Yöntemleri. Ankara: Nobel Yayın Dağıtım.

Lee, W. S., Lee, J. K. ve Moon, J. (2019). Influential attributes for the selection of luxury camping: a mixed-logit method. Journal of Hospitality and Tourism Management, 40, 88-93, https://doi.org/10.1016/j.jhtm.2019.05.004.

Louv, R. (2005). Last child in the woods: saving our children from nature deficit disorder. London, England: Atlantic Books.

Lyu, S.O., Kım, J. W. ve Bael, S. W. (2020). Family vacationers' willingness to pay for glamping travel sites: A family functioning segmentation. International Journal of Tourism Research, 1-13, https://doi.org/10.1002/jtr.2325.

Mikulić, J., Prebežac, D., Šerıć, M., ve Krešić, D. (2017). Campsite choice and the camping tourism experience: Investigating Decisive campsite attributes using relevancedeterminance analysis. Tourism Management, 59, 226-233, https://doi.org/10.1016/j.tourman.2016.07.020.

Nevşehir Hacı Bektaş Veli Üniversitesi, (2020). Nevşehir. Erişim Adresi: https://ects.nevsehir.edu.tr/ects/index/dil/tr/sayfa/76 (25.09.2020).

Nevşehir İl Kültür ve Turizm Müdürlüğü, (2020). Nevşehir. Erişim Adresi: https://nevsehir.ktb.gov.tr/TR-227537/merkez.html (25.09.2020).

Olcay, A. ve Turhan, U., (2017). Türkiye'de glamping hizmeti veren işletmelerin sahip ve yöneticilerinin "yeni turizm trendi glamping" ile ilgili görüşleri (Muğla ve Antalya Örneği). Gaziantep University Journal of Social Sciences, 16 (4), 980-996.

O'neill, M. A., Riscinto-Kozub, K. A. ve Van Hyfte, M. (2010). Defining visitor satisfaction in the context of camping oriented nature-based tourism - The driving force of quality. Journal of Vacation Marketing, 16(2), 141-156. https://doi.org/10.1177/1356766710364541.

Öztürk, H. (2019). Kamp deneyiminin ziyaretçi memnuniyeti ve yeniden ziyaret etme niyeti üzerine etkileri: Gökçetepe tabiat parkı örneği. Yükseklisans Tezi, Kırklareli Üniversitesi Sosyal Bilimler Enstitüsü, Kırklareli.

Öztürk, H. ve Başarangil, İ.(2019). Kamp deneyiminin ziyaretçi memnuniyeti ve yeniden ziyaret niyeti üzerine etkisi. Uluslararası Sosyal Araştırmalar Dergisi, 12(65), 11891201.

Petrusa, I. ve Vlahov, A. (2019). The role of glamping in development of camping tourism offer-possibilities and future prospects in The Republic Of Croatia". Proceedings of FEB Zagreb 10th International Odyssey Conference on Economics and Business, 12-15 Haziran, Opatija, Croatia, (ss. 834-844). 
Polat, E., Özdemir, S. S. ve Özdemir, M. (2014). Kırsal turizm potansiyelinin swot analizi ile değerlendirilmesi: Balıkesir örneği. Coğrafyacılar Derneği Uluslararası Kongresi Bildiriler Kitabı, 4-6 Haziran, Muğla Sıtkı Koçman Üniversitesi, MUĞLA, ss. 143-153.

Sakacova, K. L. (2013). Glamping-Nature Served on Silver Platter. Yayımlanmamış Yükseklisans Tezi Aalborg Üniversitesi Yayınları. Erişim Adresi: https://projekter.aau.dk/projekter/files/76860450/Glamping.pdf (20.09.2020).

Salo, A., Teixidor, A., Fluvia, M. ve Garriga, A. (2020). The effect of different characteristics on campsite pricing: seasonality, dimension and location effects in a mature destination. Journal of Outdoor Recreation and Tourism, 29, 1-12, https://doi.org/10.1016/j.jort.2019.100263.

Shultis, J. (2003). Recreational values of protected areas. D. Harmon ve A.D. Putney (Eds.), The full value of parks: from the economics to the intangible (ss. 59-75), Lanham, MD: Rowman and Littlefield.

Stettler, S. (2011).Sustainable event management of music festivals: An event organizer perspective. Yükseklisans Tezi, Portland State Üniversitesi, USA.

Surdu, A. (2014). How can social media be used as a communication channel between hospitality providers and customers, in synergy with other channels?. Doktora Tezi, , Delft Üniversitesi Teknoloji Bölümü, USA.

Tursab, (2019). Turizm Tesislerinin belgelendirilmesine ve Niteliklerine İlişkin Yönetmelik. Erişim adresi: https://www.tursab.org.tr/edergi?pdf=apps/OldFiles//dosya/7247/turizm-tesislerinin-belgelendirilmesine-veniteliklerine-iliskin-yonetmelik_7247_5089571.pdf (18.10.2020).

Ulrich, R.S., Simons, R.F., Losito, B.D., Fiorito, E., Miles, M.A., ve Zelson, M. (1991). Stress recovery during exposure to natural and urban environments. Journal of Environmental Psychology, 11(3), 201-230.

Urdal, M. ve Uğurlu, K. (2016). Kamp turizminde glamping işletmeciliği: kırklareli ili için bir model önerisi. 17. Ulusal Turizm Kongresi, 20-23 Ekim, Muğla, (ss.1213-1224).

Vrtodušić Hrgović, A. M., Cvelıć Bonıfačıć, J. ve Lıcul, I. (2018). Glamping-new outdoor accommodation. Ekonomska misao i praksa, Dubrovnik, 27(2), 621-633.

Wellner, K. (2015). User innovators in the silver market. Wiesbaden: Springer Gabler. 